\title{
E-Budgeting ATK pada Badan Pengelolaan Keuangan dan Aset Daerah Kabupaten Gianyar
}

\author{
I Gusti Ayu Jasmiari ${ }^{1}$, Wayan Gede Suka Parwita ${ }^{2}$, Ni Putu Suci Meinarni ${ }^{3}$ \\ 1,2,3Program Studi Teknik Informatika, STMIK STIKOM Indonesia \\ email: 1'jasmiary17@gmail.com, ${ }^{2}$ gede.suka@gmail.com, ${ }^{3}$ sucimeinarni@stiki-indonesia.ac.id
}

\begin{abstract}
Financial Management and District Asset Agency of Gianyar District is an official government agent of Gianyar District that has the authority to execute the district autonomy in terms of income, financial management, and asset administration. The agency has faced the difficulties in budgeting process of stationary which is not transparent, that will be lead to misappropriation of the budget and there is no clear and detail of the budget of the stationary. This condition will cause inefficient of budgeting for the stationary. The purpose of this research is to build an e-budgeting of stationary on Financial Management and District Asset Agency of Gianyar District that has the correlation with budgeting plan of stationary where a system can be used to manage the budget of the stationary in terms of additional transaction or deduction of stationary. In this research, there are four methods used, those are interview, observation, documentation and literary research. The design of the system is done by analyzing the needs system and was designed by using Data Flow Diagram (DFD) in order to design system and data flow. In this design, the system has been made and a trial of functional system has been done by using Blackbox Testing Method using 24 scenario of trial system, which from that trial showed can be concluded that the system was done appropriately based on the design system.
\end{abstract}

Keywords: e-budgeting, budgeting, design system, stationary.

\section{PENDAHULUAN}

Badan Pengelolaan Keuangan dan Aset Daerah Kabupaten Gianyar merupakan salah satu organisasi perangkat daerah yang melaksanakan unsur otonomi daerah di bidang pendapatan, pengelolaan keuangan dan penatausahaan aset. Sebagai salah satu organisasi perangkat daerah Badan Pengelolaan Keuangan dan Aset Daerah Kabupaten Gianyar dituntut untuk memperhatikan pengendalian intern terhadap pengelolaan keuangan yang dilakukan, salah satunya pengendalian terhadap sistem pengadaan barang dan jasa khususnya pengadaan alat tulis kantor. Badan Pengelolaan Keuangan dan Aset Daerah Kabupaten Gianyar menyadari pentingnya penganggaran alat tulis kantor yang terkomputerisasi dan pengolahan data yang terpusat sehingga terwujudnya akuntabilitas dan transaparansi penggunaan anggaran alat tulis kantor yang terjadi. Tata kelola pemerintahan yang baik (good governance) memiliki hal terpenting yaitu transparansi, akuntabilitas, dan partisipatif (Zeyn, 2011).

Badan Pengelolaan Keuangan dan Aset Daerah Kabupaten Gianyar mengalami kendala dalam proses penganggaran alat tulis kantor, dimana proses penganggaran yang terjadi tidak transparan, mudah terjadinya penyelewengan penggunaan anggaran, dan tidak adanya kejelasan rincian pengeluaran alat tulis kantor yang real time. Hal ini mengakibatkan terjadinya penggunaan anggaran secara berlebihan yang 
pada akhirnya menyebabkan inefisiensi terhadap anggaran alat tulis kantor yang dianggarkan.

Untuk proses pengolahan anggaran alat tulis kantor yang berjalan saat ini dilakukan dengan cara mencatat data pengajuan dan pengeluaran alat tulis kantor pada file Microsoft Excel yang kemudian direkapitulasi untuk dilakukan proses pemesanan oleh Bendahara Pengurus Barang. Hal ini menyebabkan terjadi penumpukan arsip kartu barang yang menyebabkan arsip tersebut sering kali sulit ditemukan bahkan hilang dan sulitnya mengetahui realisasi anggaran alat tulis kantor di masing-masing bidang jika laporan belum dibuat. Hal tersebut mengakibatkan Bagian Umum dan Kepegawaian tidak dapat melihat kembali data pengeluaran alat tulis kantor pada kartu barang dan realisasi anggaran yang terjadi setiap harinya. Hal inilah yang menjadi kendala karena menimbulkan keterlambatan informasi pengadaan alat tulis kantor periode berikutnya yang akan di sampaikan kepada Kepala Badan. Untuk mengatasi masalah tersebut, diperlukan sistem yang yang dapat mencatat transaksi penambahan, pengurangan, dan persediaan alat tulis kantor serta menyajikan laporan anggaran serta laporan realisasi anggaran. Oleh karena itu judul penelitian yang akan diulas penulis adalah E-Budgeting Alat Tulis Kantor pada Badan Pengelolaan Keuangan dan Aset Daerah Kabupaten Gianyar.

E-budgeting merupakan sistem informasi yang digunakan untuk penyusunan anggaran guna meningkatkan efisiensi dan efektivitas dalam proses penganggaran (Gunawan, 2016). Terdapat beberapa penelitian terdahulu yang penulis gunakan sebagai referensi. Penelitian pertama dengan judul penelitian "Sistem Informasi EBudgeting Anggaran Perjalanan Dinas pada Universitas Islam Negeri Raden Patah Palembang" karya (Meytasari, 2016). Penelitian ini menghasilkan sistem informasi ebudgeting anggaran perjalan dinas yang dapat membantu proses manajemen penganggaran dan memudahkan dalam perhitungan biaya perjalanan dinas, serta dapat memberikan realisasi kegiatan. Penelitian lain yang terkait adalah penelitian dengan judul "Sistem Informasi Budgeting untuk Perguruan Tinggi" karya (Sundjaja, Tundjung, \& Puspita, 2011). Penelitian ini bertujuan untuk mengintegrasikan data dan informasi anggaran yang dibutuhkan oleh Perguruan Tinggi..

Penelitian dengan judul "E-Budgeting Alat Tulis Kantor pada Badan Pengelolaan Keuangan dan Aset Daerah Kabupaten Gianyar" memiliki persamaan terhadap penelitian terdahulu dimana, pada proses pengolahan data dilakukan secara tidak terpusat, hal ini menyebabkan petugas terkait sulit untuk mengetahui realisasi anggaran yang terjadi serta adanya keterlambatan informasi mengenai anggaran yang tersisa dalam suatu periode penganggaran. Perbedaan dari penelitian terdahulu adalah objek penelitian berfokus pada penganggaran alat tulis kantor pada Badan Pengelolaan Keuangan dan Aset Daerah Kabupaten Gianyar yang pokok pembahasannya berkaitan dengan pengolahan anggaran alat tulis kantor yang meliputi transaksi pengajuan alat tulis kantor, pengurangan stok alat tulis kantor sampai dengan menghasilkan laporan realisasi anggaran dan laporan persediaan alat tulis kantor yang dapat digunakan sebagai dasar untuk pengadaan alat tulis kantor di periode berikutnya. 


\section{RANCANGAN DAN IMPLEMENTASI}

\section{Gambaran Umum Sistem}

Sistem digambarkan dengan menggunakan system flow diagram yang memberikan gambaran umum dari kegiatan pemrosesan yang akan direncanakan atau yang seharusnya dikerjakan (Amsyah, 2005). Pembangunan sistem yang akan diajukan oleh penulis akan disesuaikan dengan proses penganggaran alat tulis kantor yang berjalan saat ini pada kantor Badan Pengelolaa Keuangan dan Aset Daerah Kabupaten Gianyar. Gambaran umum sistem dapat dilihat pada Gambar 1.

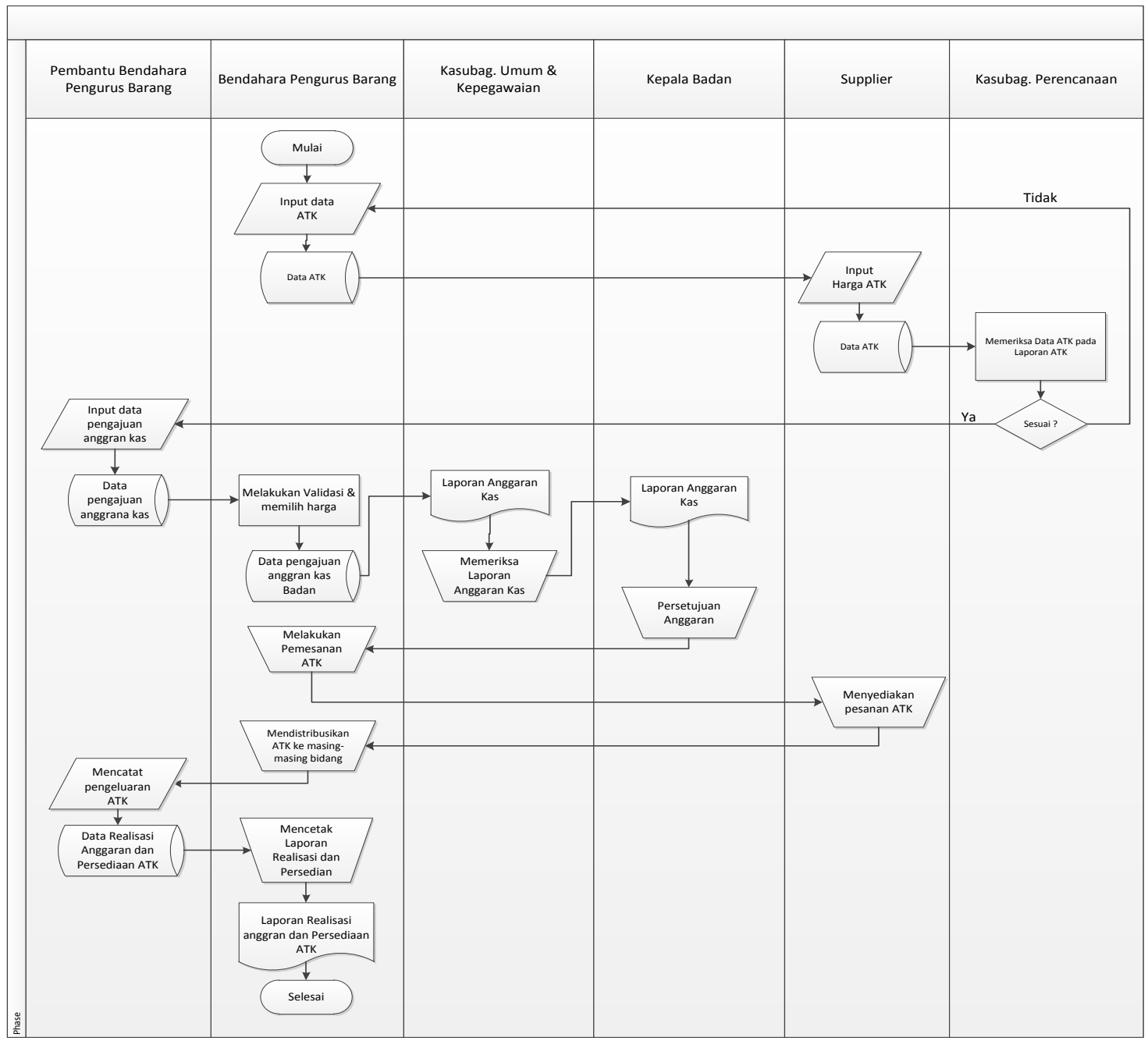

Gambar 1. Gambaran Umum Sistem

\section{Perancangan Sistem}

Data Flow Diagram (DFD) adalah representasi grafik yang menggambarkan aliran informasi dan transformasi informasi yang diaplikasikan sebagai data yang mengalir dari masukan (input) dan keluaran (output) (Rosa dan Shalahuddin, 2016). Gambar 2 menggambarkan Data Flow Diagram 0 dari E-Budgeting Alat Tulis Kantor Pada Badan Pengelolaan Keuangan dan Aset Daerah Kabupaten Gianyar.

\section{Data Model}

Physical Data Model E-Budgeting Alat Tulis Kantor ini memperlihatkan relasi dari tujuh tabel yang saling berhubungan yaitu tb_user, tb_supplier, tb_hargaATK, 
tb_PeriodeAnggaran, tb_ATK, tb_Penganggaran, dan tb_Pengeluaran ATK. Data model digambarkan dengan physical data model (Rosa dan Shalahuddin, 2016) yang ditunjukkan pada Gambar 3.

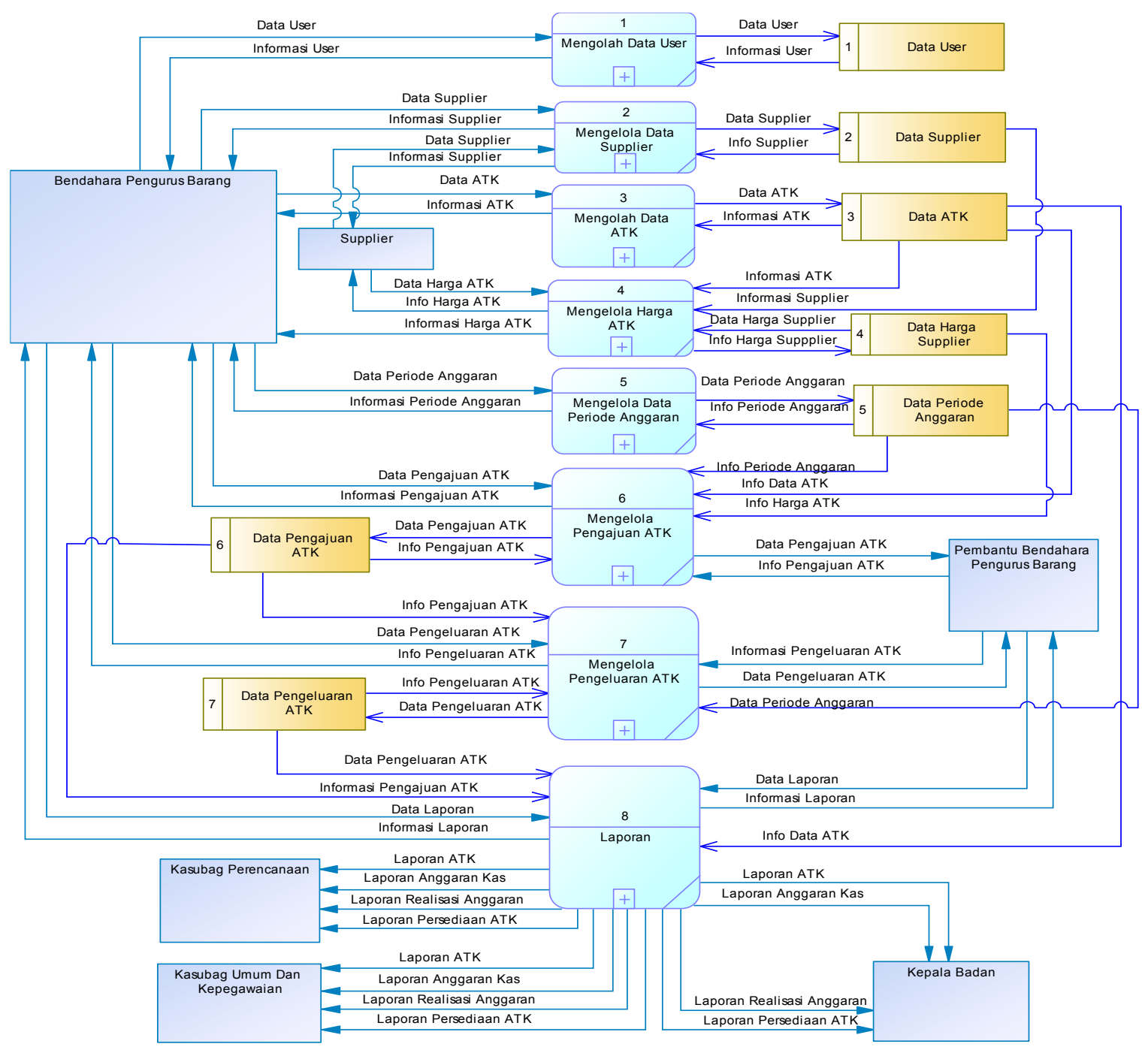

Gambar 2. Data Flow Diagram 0

\section{Implementasi}

Implementasi sistem merupakan tahapan selanjutnya yang dilakukan setelah proses analisis dan perancangan sisem. Implementasi dilakukan untuk menerapkan hasil dari analisis dan perancangan yang telah dibuat sebelumnya agar menjadi sebuah sistem yang siap digunakan, dan nantinya akan dilakukan pengujian terkait dengan fungsi-fungsi yang terdapat pada sistem untuk menentukan apakah sistem sudah sesuai dengan yang diharapkan atau tidak. Hasil dari implementasi user interface ini adalah suatu sistem pengelolaan anggaran alat tulis kantor yang sesuai dengan perancangan dan dapat berjalan dengan baik. Sistem diimplementasikan dengan framework Laravel. Laravel adalah sebuah framework PHP yang dirilis dibawah lisensi MIT, dibangun dengan konsep MVC (Model View Controller) (Aminudin, 2015). Berikut merupakan implementasi dari E-Budgeting Alat Tulis 
Kantor pada Badan Pengelolaan Keuangan dan Aset Daerah Kabupaten Gianyar.

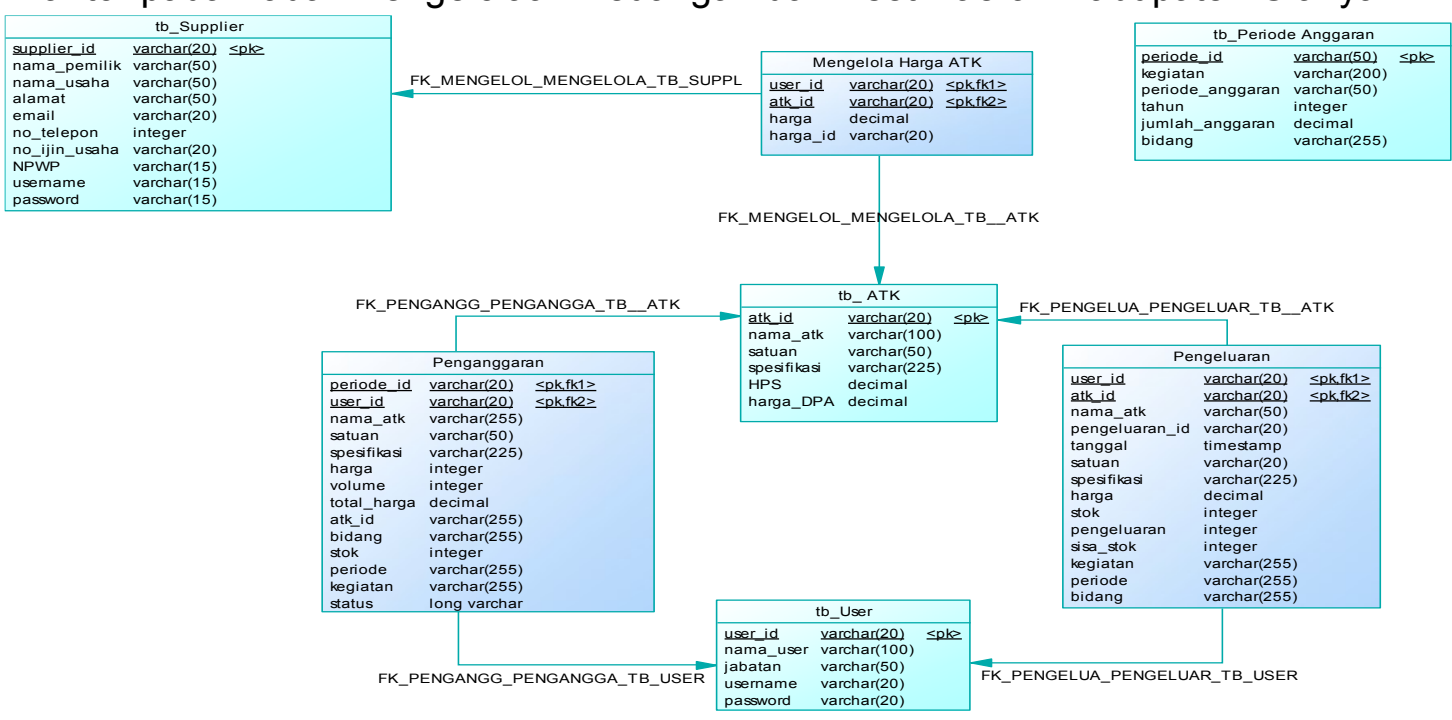

Gambar 3. Merupakan Physical Data Model dari E-Budgeting Alat Tulis Kantor pada Badan Pengelolaan Keuangan dan Aset Daerah Kabupaten Gianyar.

- Halaman Akses Publik

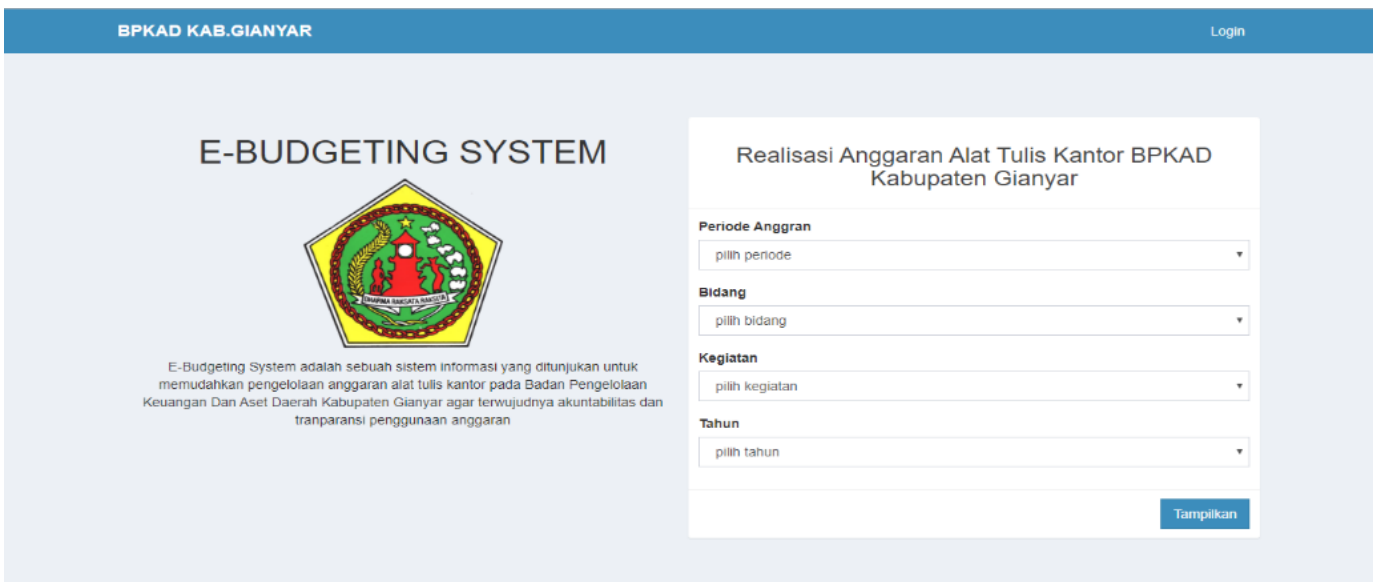

Gambar 4. Merupakan halaman akses publik dimana halaman ini merupakan halaman yang pertama kali muncul ketika pengguna mengakses sistem

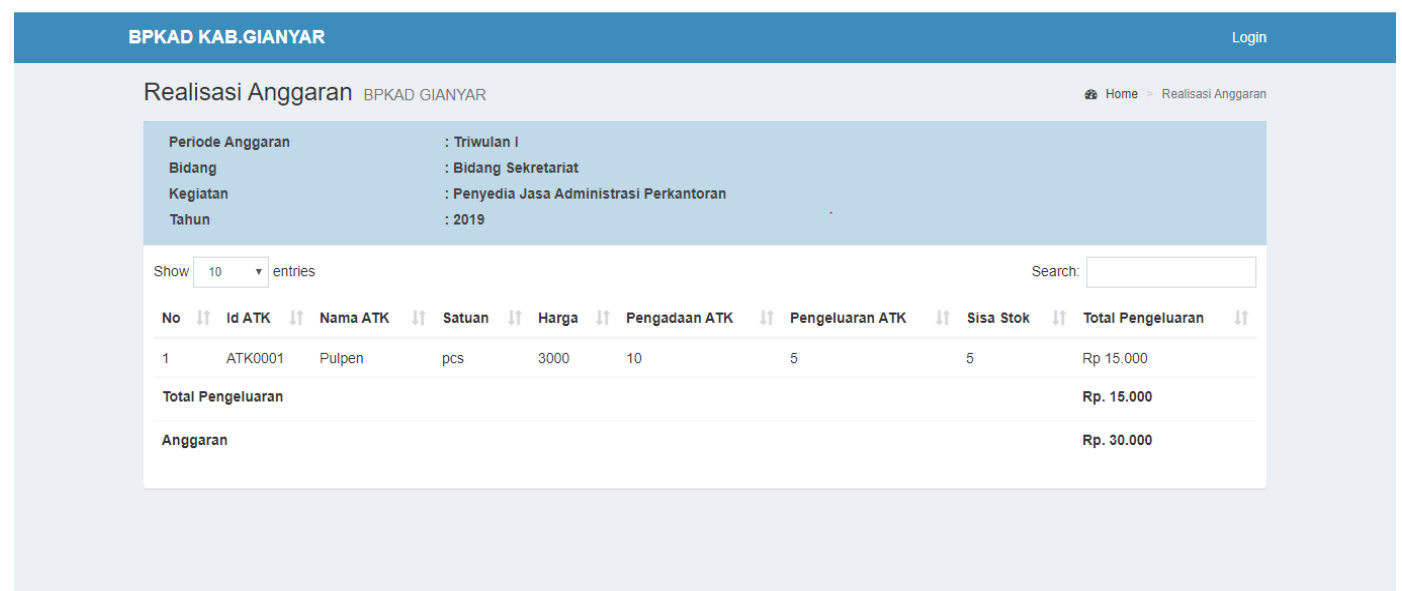

Gambar 5. merupakan halaman realisasi anggaran dan merupakan halaman aksi lanjutan dari halaman 
akses publik

- Halaman Login



Gambar 6. Merupakan halam login. Untuk dapat mengakses halaman ini pengguna memerlukan username dan password yang telah terdaftar sebelumnya.

- Halaman Harga Alat Tulis Kantor

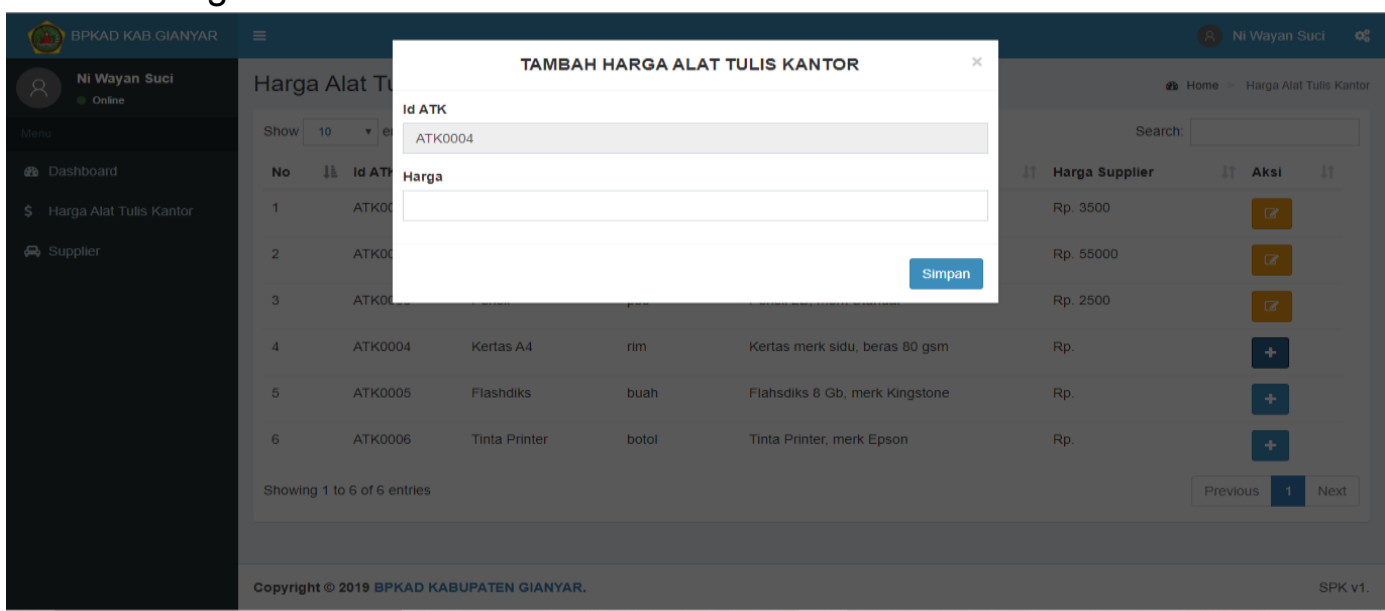

Gambar 7. Merupakan halaman yang dapat diakses oleh Supplier untuk dapat mengelola harga alat tulis kantor yang ditawarkan.

- Halaman Pengajuan Alat Tulis Kantor

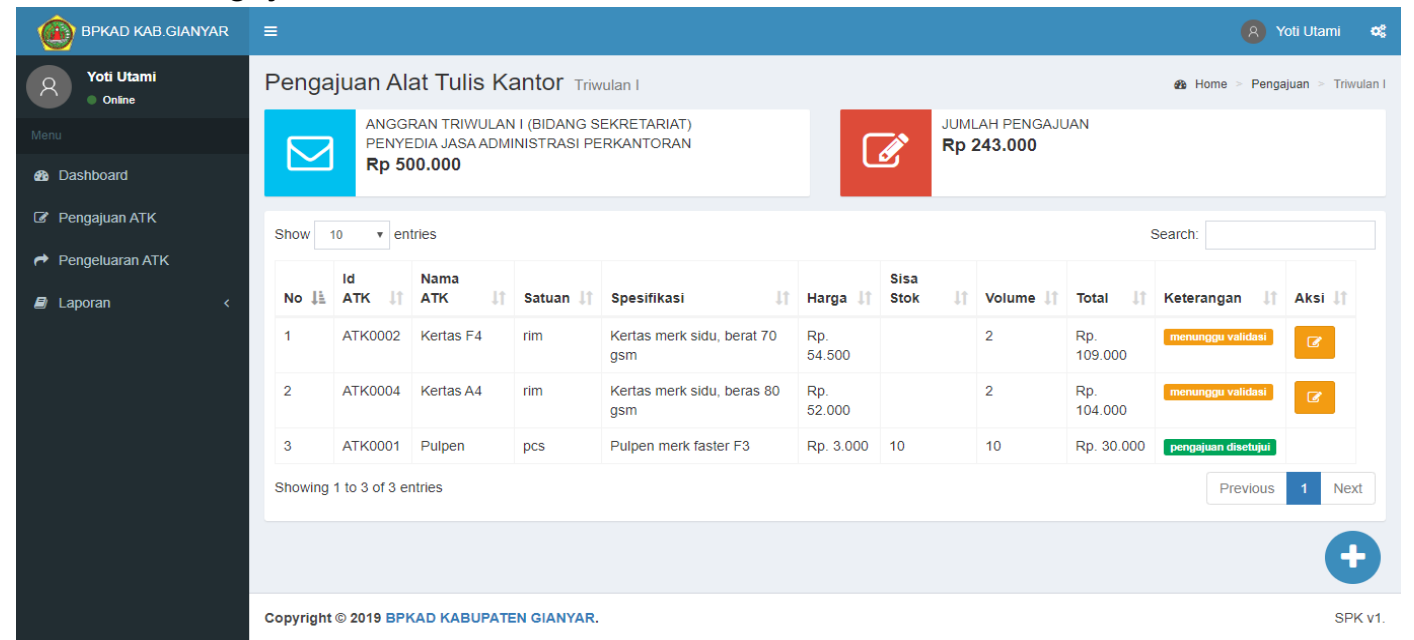

Gambar 8. Merupakan halaman pengajuan yang dapat dikases oleh Pembantu Bendahara Pengurus Barang. 


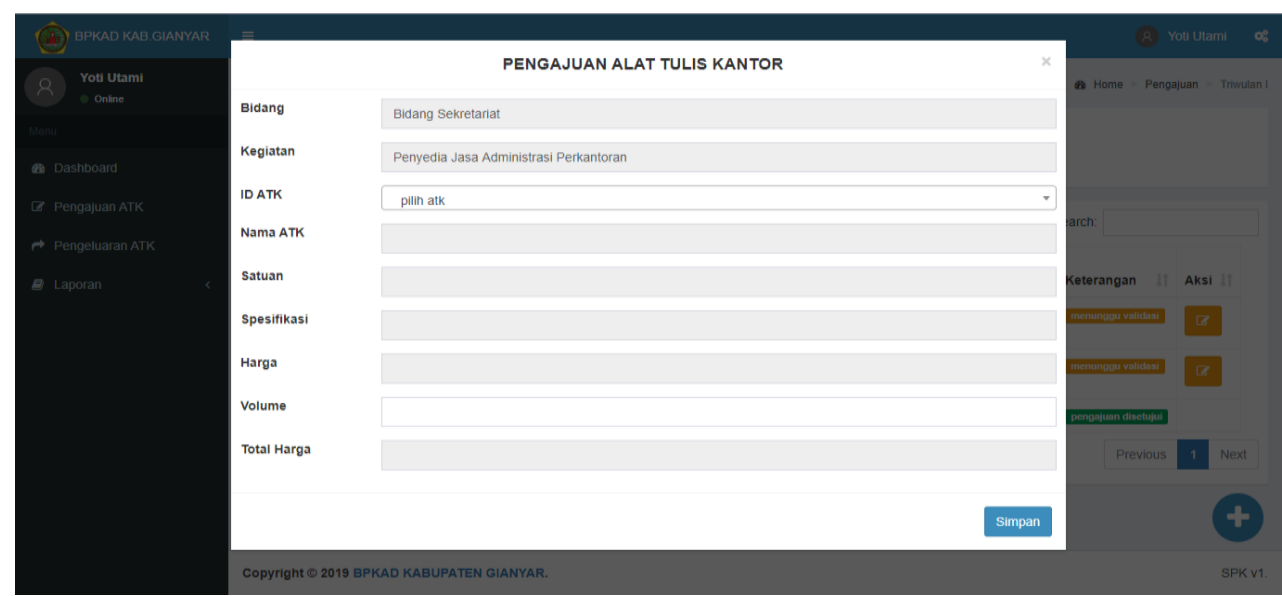

Gambar 9. Halaman Tambah Pengajuan Alat Tulis Kantor

- Halaman Pemilihan Harga Alat Tulis Kantor

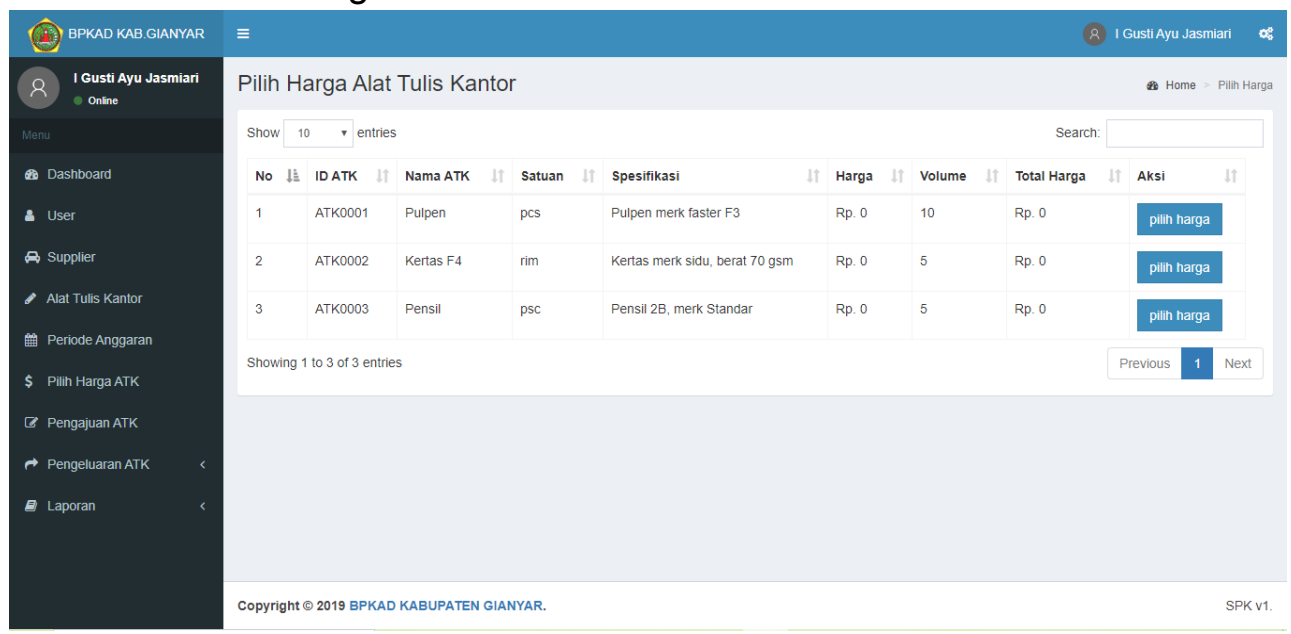

Gambar 10. Merupakan halaman pemilihan harga alat tulis kantor yang dapat diakses oleh Bendahara Pengurus Barang



Gambar 11. Merupakan halaman pilih harga supplier. Pada halaman ini Bendahara Pengurus Barang dapat memilih harga alat tulis kantor yang ditawakan oleh masing-masing supplier. 
- Halaman Validasi Pengajuan Alat Tulis Kantor

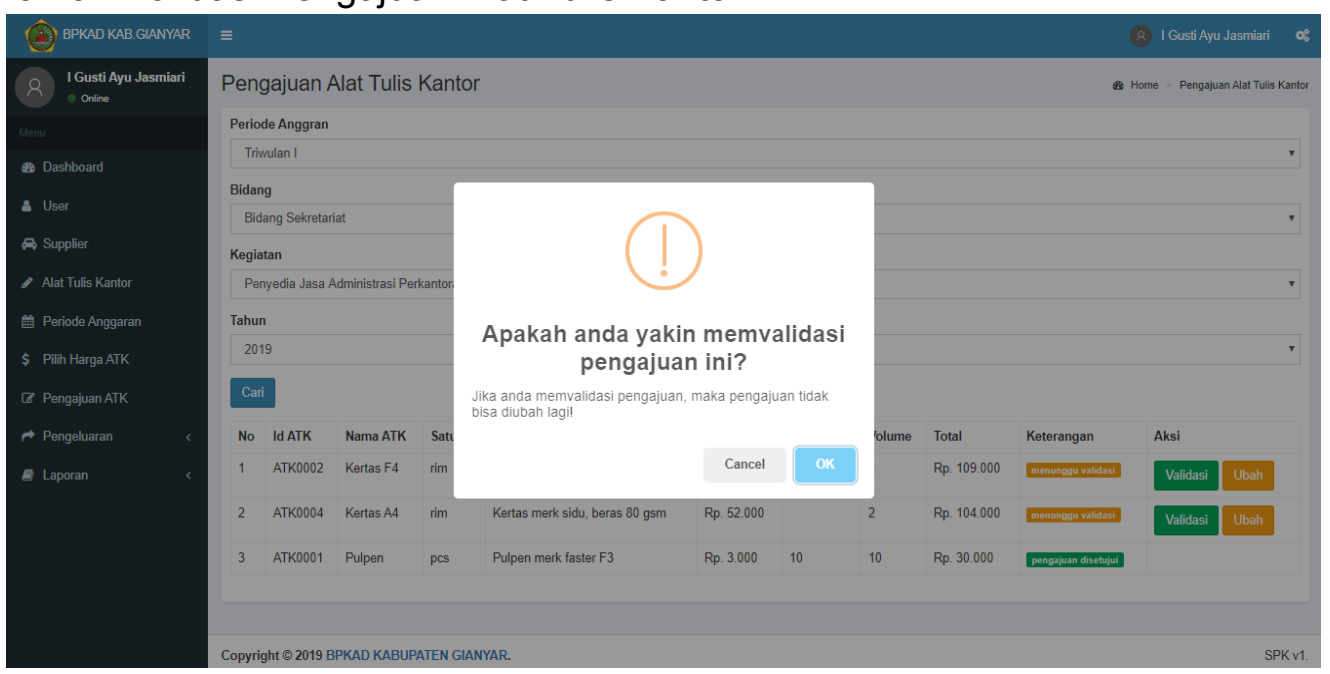

Gambar 12. Halaman Validasi Pengajuan Alat Tulis Kantor

- Halaman Pengeluaran Alat Tulis Kantor

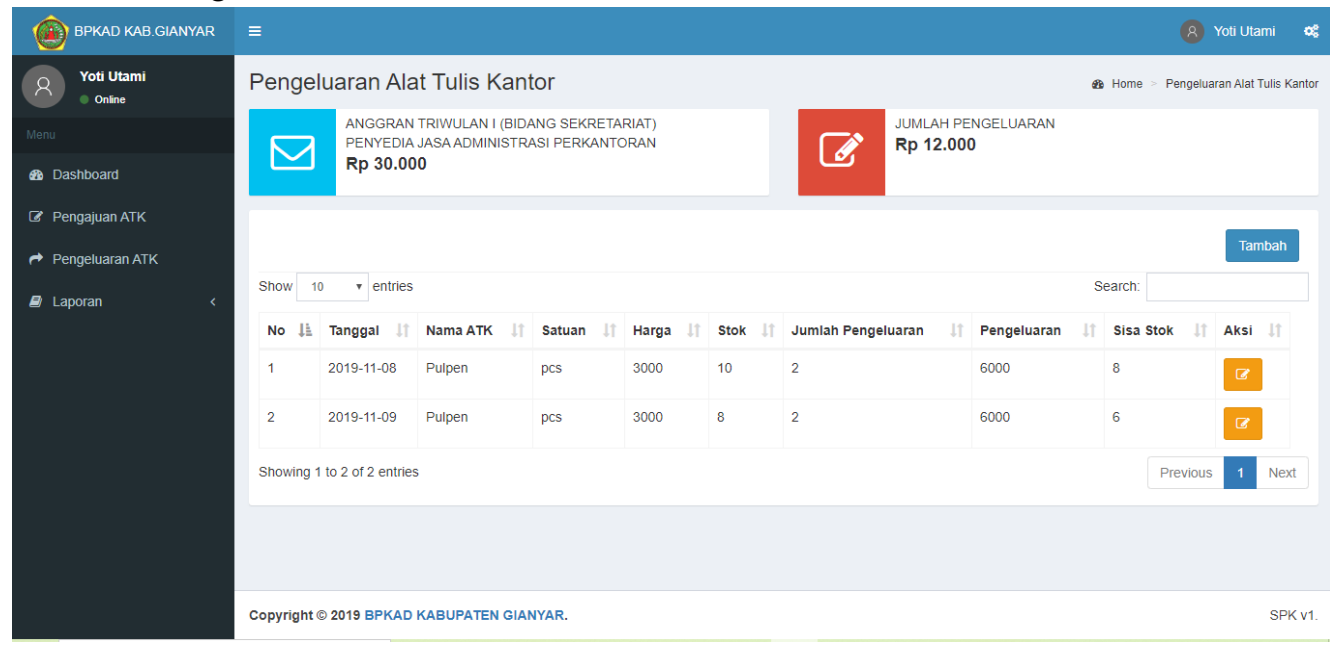

Gambar 13. Merupakan halaman pengeluaran alat tulis kantor yang dapat diakses oleh Pembantu Bendahara Pengurus Barang.

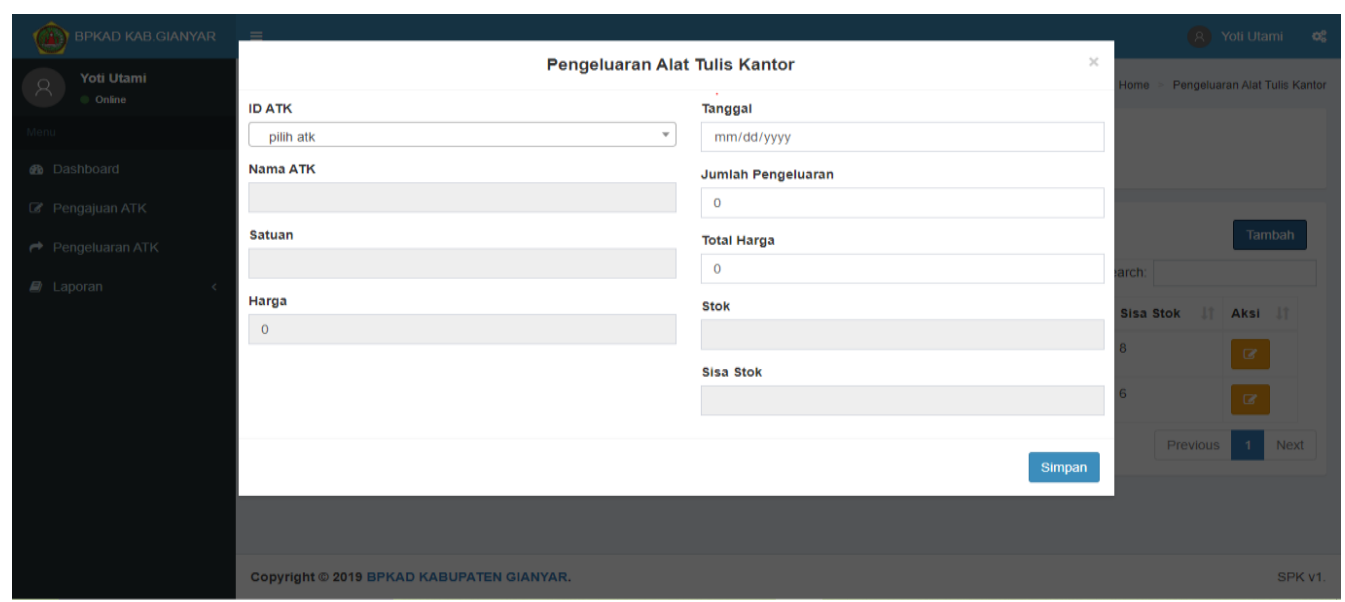

Gambar 14. Halaman Tambah Pengeluaran Alat Tulis Kantor 
- Laporan Alat Tulis Kantor

\begin{tabular}{|c|c|c|c|c|c|c|}
\hline (2) BPKAD KABGGANYAR & \multicolumn{5}{|l|}{$\equiv$} & 8) I Gusti Ayu Jasmiari \\
\hline (8) IGusti Ayu Jasmiari & \multicolumn{4}{|c|}{ Laporan Alat Tulis Kantor } & & ש Home = Daia Alat Tulis Kantor \\
\hline Menu & \multicolumn{6}{|l|}{ celak } \\
\hline \& Dashboard & \multicolumn{4}{|c|}{ Show $10 \quad$ entries } & \multicolumn{2}{|r|}{ Search: } \\
\hline \& User & IOATK & IE Nama ATK & It satuan & It Spesifikasi & If HPs & It Harga DPA \\
\hline Supplier & Aтксо01 & Pulpen & pcs & Pulpen meik faster F3 & Rp. 3.000 & Rp. 4.000 \\
\hline - Alat Tuls Kantor & ATKcooor & Kertas $F 4$ & rim & Kertas merk sidu, berat $70 \mathrm{gsm}$ & Rp. 54.000 & Rp. 55.000 \\
\hline 䟧 Periode Anggaran & ATK0003 & Pensil & $\mathrm{psc}$ & Pensil 2B, meik Siandar & Rp. 2.500 & Rp. 3.000 \\
\hline \multirow{3}{*}{$\begin{array}{l}\text { \$ Pilih Harga ATK } \\
\text { \& Pengajuan ATK }\end{array}$} & ATK0004 & Ketras A4 & rim & Kertas merk sidu, beras 80 gsm & Rp. 50.000 & Rp. 52.000 \\
\hline & ATKK005 & Flashdiks & buan & Flansdilis $8 \mathrm{~Gb}$, merk Kingstone & Rp. 78.000 & Rp. 80.000 \\
\hline & AтKс0006 & Tina Printer & botol & Tinta Pinter, merk Epson & Rp. 49.000 & Rp. 50.000 \\
\hline$\nrightarrow$ Pengeluaran & ATK0007 & Map Folio Kerias & buan & Map folio ukuran F4, merk Sidu & Rp. 1.000 & Rp. 1.200 \\
\hline E Laporan & \multicolumn{4}{|c|}{ Showing 1 to 7 of 7 entries } & & \begin{tabular}{|l|l|} 
Previous & 1 \\
Next
\end{tabular} \\
\hline
\end{tabular}

Gambar 15. Laporan Alat Tulis Kantor

- Laporan Anggaran Kas

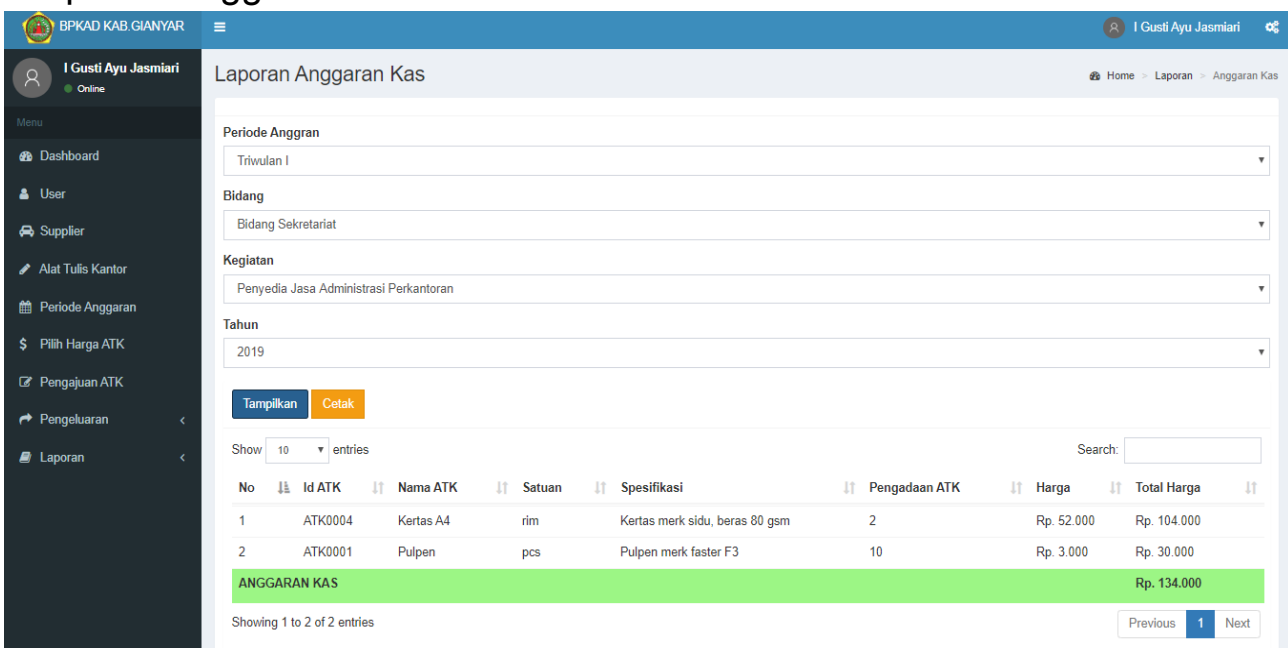

Gambar 16. Laporan Anggaran Kas

- Laporan Realisasi Anggaran

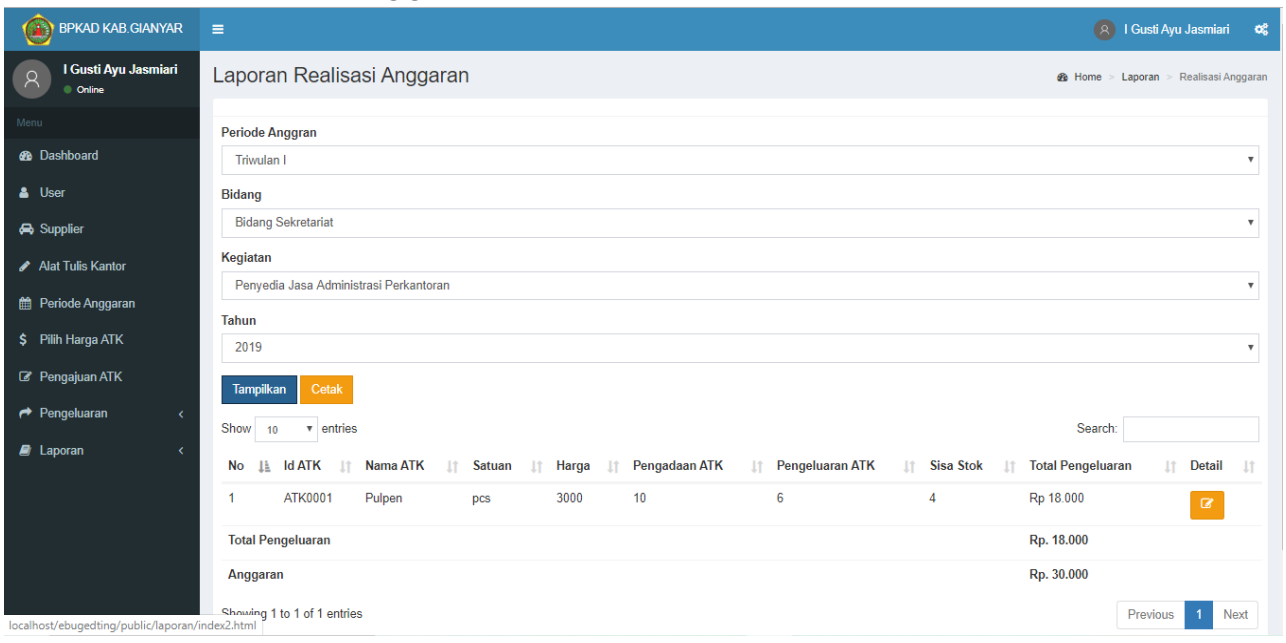

Gambar 17. Laporan Realisasi Anggaran 
- Laporan Persediaan Alat Tulis Kantor

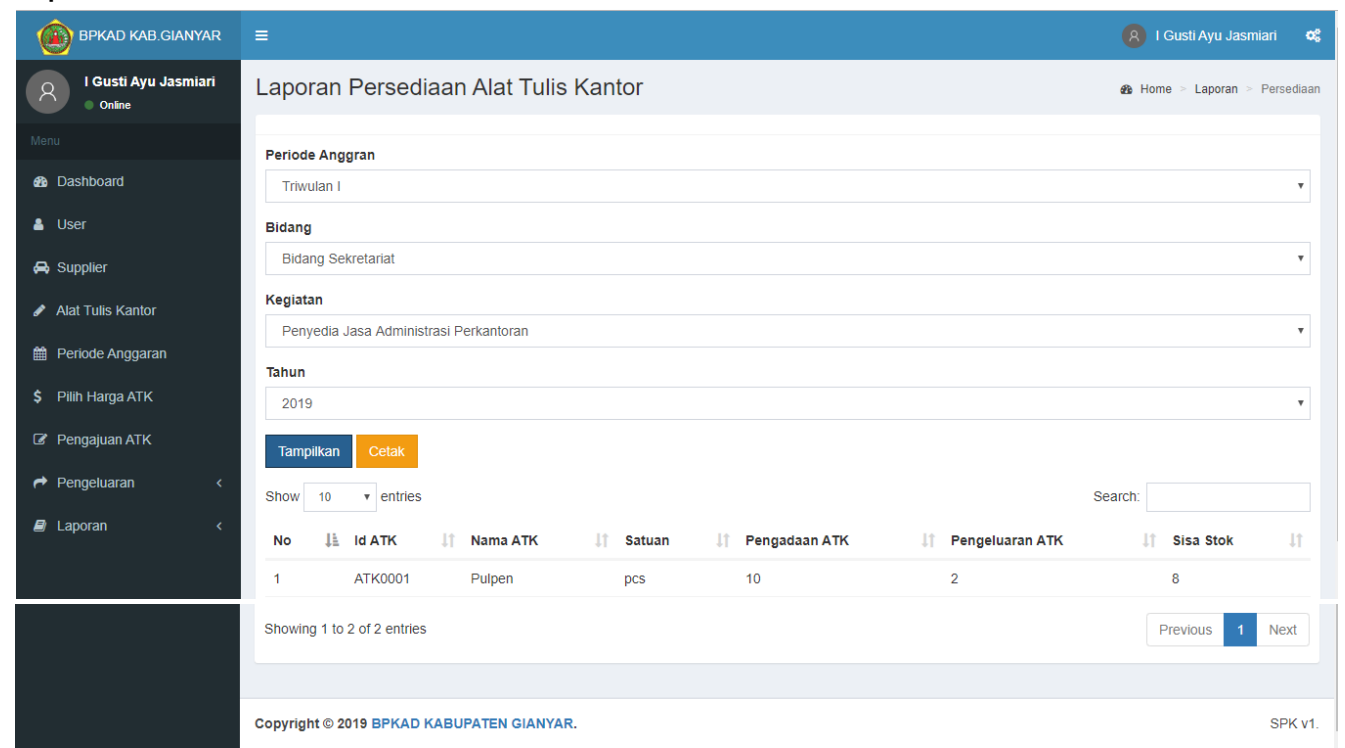

Gambar 18. Laporan Persediaan Alat Tulis Kantor

\section{HASIL DAN PEMBAHASAN}

\section{Pengujian Sistem}

Pengujian Sistem pada penelitian ini mengimplementasikan indikator-indikator yang terdapat pada metode Black Box Testing (Nidhra, 2012), dimana pengujian terfokus pada fungsional sistem. Tujuan dari dilakukannya pengujian ini adalah untuk mengetahui sistem yang dibangun dan output informasi yang dihasilkan oleh sistem apakah telah sesuai dengan rancangan yang dilakukan pada proses perancangan yang telah dilakukan sebelumnya oleh penulis. Berdasarkan hasil pengujian dengan metode Black Box Testing yang telah dilakukan dengan mengimplementasikan 24 skenario uji dan dengan 2 statement (valid dan invalid) pengujian untuk menguji fungsional sistem ditemukan hasil sebagai berikut. Apabila seluruh fungsional pada sistem telah berjalan sesuai dengan perancangan yang telah dibuat, maka hasil uji dinyatakan sesuai (valid). Kemudian, apabila terdapat bagian fungsional pada sistem yang berjalan tidak sesuai dengan perancangan yang telah dibuat, maka hasil uji dinyatakan tidak sesuai (invalid).

\section{SIMPULAN}

Berdasarkan hasil penelitian yang dilakukan dapat disimpulkan bahwa $E$ Budgeting Alat Tulis Kantor pada Badan Pengelolaan Keuangan dan Aset Daerah Kabupaten Gianyar dirancang dan dibangun memalui beberapa tahapan, yaitu identifikasi masalah, pengumpulan data, analisis data, perancangan sistem dengan menggunakan pemodelan Data Flow Diagram (DFD), Conceptual Data Model (CDM) dan Physical Data Model (PDM) untuk menggambarkan relasi database, sedangkan pembangunan sistem menggunakan Sublime dan MySQL sebagai database serta menguji fungsional sistem menggunakan metode Black Box Testing.

Dengan pengujian dengan metode Balck Box Testing yang telah dilakukan dengan 24 skenario untuk menguji fungsional sistem, dapat disimpulkan bahwa $E$ Budgeting Alat Tulis Kantor pada Badan Pengelolaan Keuangan dan Aset Daerah 
yang dibangun sudah berjalan sesuai dengan yang diharapkan karena semua fungsional sistem telah sesuai dengan perancangan yang dilakukan.

Berdasarkan kesimpulan yang telah diuraikan, adapun saran yang dapat penulis berikan melalui proses penelitian selanjutnya adalah pengembangan sistem ke dalam aplikasi mobile dan dapat dikembangkan lagi dengan menambah fitur-fitur lain seperti : fitur pemesanan alat tulis kantor dan fitur pembayaran, sehingga semua proses penganggaran alat tulis kantor dapat dilakukan pada sistem.

\section{DAFTAR PUSTAKA}

Aminudin. 2015. Cara Efektif Belajar Framework Laravel. IImu Teknologi Informasi.

Amsyah, Z. 2005. Manajemen Sistem Informasi. In ch. 4 pp 83.

Gunawan, D. R. 2016. Penerapan Sistem E-Budgeting Terhadap Transparansi Dan Akuntabilitas Keuangan Publik (Studi Pada Pemerintah Kota Surabaya). Jurnal Akuntansi.

Meytasari. 2016. Sistem Informasi E-Budgeting Anggaran Perjalanan Dinas pada Universitas Islam Negeri Raden Patah Palembang.

Nidhra, S. 2012. Black Box and White Box Testing Techniques - A Literature Review. International Journal of Embedded Systems and Applications. https://doi.org/10.5121/ijesa.2012.2204

Rosa dan Shalahuddin. 2016. Rekayasa Perangkat Lunak (Terstrukur dan Berorientasi Objek). In Informatika Bandung. https://doi.org/10.1209/epl/i2006-10054-4

Sundjaja, A. M., Tundjung, H., \& Puspita, I. 2011. Sistem Informasi Budgeting Untuk Perguruan Tinggi. Seminar Nasional Informatika, (semnasIF), 146-152.

Zeyn, E. 2011. Pengaruh Penerapan Good Governance dan Standar Akuntansi Pemerintahan terhadap Akuntabilitas Keuangan. Trikonomika. 
160 | I Gusti Ayu Jasmiari, Wayan Gede Suka Parwita, Ni Putu Suci Meinarni 